\title{
The Utilization of E-Learning Platforms During the Covid-19 Pandemic
}

\author{
Kivah Aha Putra ${ }^{1}$, Ratna Nulinnaja ${ }^{2, *}$, Siti Faridah ${ }^{3}$ \\ 1,2,3 Universitas Islam Negeri Maulana Malik Ibrahim Malang \\ *Corresponding author.Email: ratna_nulinnaja@uin-malang.ac.id
}

\begin{abstract}
The purpose of this research is to obtain the largest percentage of platforms used by students so that learning is no longer constrained by the use of the platform but at the stage of how to be able to absorb the material that has been transferred by the lecturer so that learning is more meaningful according to constructivism theory. This research is classified as a descriptive qualitative research, by conducting a survey through data collection techniques from online questionnaires to students of UIN Maulana Malik Ibrahim Malang from the Faculty of Science and Technology and the Faculty of Tarbiyah and Teacher Training as samples. The results of the online questionnaire show that social media platforms (Instagram, Whatshapp, Facebook) rank first with a percentage of 54\%, this shows that almost more than half of the respondents use social media platforms. The second place is e-learning of UIN Maulana Malik Ibrahim Malang and google classroom with a percentage of $47.6 \%$, these two platforms are mostly used by students and lecturers in distance learning. As many as $40 \%$ of students and lecturers also use google meet for online learning. The google meet platform has a higher percentage than the zoom platform which is only $12.4 \%$, this is because the use of the zoom platform is limited by time and consumes more quota than google meet. Apart from the five platforms that have been mentioned, there are other platforms with a percentage below $2 \%$ such as Moodle, Quipper, Edmodo, and Zenius education.
\end{abstract}

Keywords: Platform, E-Learning, Online, Covid-19

\section{INTRODUCTION}

The pandemic faced around the world is the Corona Virus Disease 2019 (Covid-19) pandemic. This is of course very influential on people's lives in the world, one of which is for the Indonesian people. The existence of this condition, the Indonesian government implements restrictions on activities outside the home through social distancing policies (maintaining social distancing, avoiding crowds, and even better at home) this condition is said to be physical distancing by keeping a minimum distance between people of 2 meters since early March 2020 [1]. This can be seen from the decline in community activity outside the home which causes deserted streets, decreases economic activity and stops education. The government considered this implementation ineffective so that the government updated the regulations with Large-Scale Social Restrictions (PSBB). This rule makes it difficult to carry out activities. This condition is carried out to inhibit the number of Covid-19 transmission in Indonesia.

The global spread of coronavirus disease 2019 (COVID-19) is triggering a range of public health responses. Schools and Universities closures are some of the highest-profile social (physical) distancing measures used to slow the spread of this infectious disease [2]. Educational activities must stop for a moment to regulate the conditions for how to carry out educational activities during this pandemic. In accordance with the government circular through the Indonesian Minister of Education and Culture Circular No. 3 of 2020 concerning the prevention of Covid-19 in education units [3], all educational activities including at the tertiary level in Indonesia, one of which is at UIN Maulana Malik Ibrahim Malang made a firm decision based on a circular from the government with reference to implement learning activities in individual homes or through distance learning. If in the past all learning activities were carried out on campus, now it must be done at home because of the Covid-19 pandemic. Likewise, lecturers and staff alternate between WFH (Work from Home) and WFO (Work from Office) in turns. This is done to support the government in reducing the level of transmission of Covid-19 in Indonesia. 
Technology becomes an essential parts of our daily life. E-learning, internet and computers have been used vitally in teaching and learning process [4]. The distance learning process is carried out using various existing platforms. Several platforms can be accessed by all lecturers and students. Choosing the right platform is a platform that is not only easily accessible to lecturers but also easily accessible to students. Because the use of platforms that are considered easy by lecturers is not necessarily easy for students to use, and vice versa. If a platform is determined that is considered easy and efficient for use by lecturers and students, the distance learning process will run well and the material can be delivered as expected, so that the objectives of learning have been achieved.

The implementation of online learning is not limited to crisis situations such as the current pandemic, online learning has been suggested as a substitute for face-toface learning. As part of online learning, video-based distance learning, which allows two-way interaction between spaces Different classes using remote imaging systems, have been widely used since the 1990s. In addition, video-based distance education, which is recognized as an online education method, is suitable for the 21 st century educational environment to facilitate two-way interaction, participation in learning, class achievement, and levels of satisfaction similar to that of face-to-face classes [5].

There are several previous studies that became the background for researchers to conduct research, namely as follows: 1) "E-learning in students' perceptions" is explained based on e-learning analysis in the sense that students have high accessibility, namely $91 \%$ with the use of light $83 \%$. A good assessment of students' perceptions of e-learning provides a big role in the implementation of learning with e-learning, which can be done with a blended learning pattern as a form of learning that collaborates face-to-face e-learning [6]. 2)"The level of reusability and satisfaction of evernote as an e-learning platform for basic nursing science courses at the Faculty of Nursing at the University of Padjadjaran" explained that the Evernote application is in demand by students but they have not been able to see its benefits in learning because the research was conducted on a trial version of the online course [7]. 3) Utilization of the WhatsApp as a media of communication between lecturers and students in supporting learning activities (student study of UIN Imam Bonjol Padang) resulted in more than $70 \%$ of students stating that the WhatsApp application had a positive impact on their learning and supporting activities. improve their communication with lecturers. So whatsapp is a medium that has benefits, among others, as a means of communication and support for learning activities. The ease of use of WhatsApp makes students feel helped by this application and is an important and preferred communication tool for students [8].
Some of the arguments above are related to elearning. Accessibility, affordability, flexibility, pedagogical learning, lifelong learning, and policy to name a few arguments related to online pedagogy. It is said that online learning mode easily accessible and can even reach rural and remote areas. It is considered being a relatively cheaper mode of education in terms of lower costs transportation, accommodation, and the overall cost of institution-based learning. Flexibility is another interesting aspect of online learning; a student can schedule or plan their time to complete the courses available online. Combining face-to-face lectures with technology gives rise to mixed learning and ipped classrooms; this type of learning environment can enhance student learning potential. Students can study anytime and anywhere, thereby developing new skills in a process leading to lifelong learning. The government also realizes the growing importance of online learning in this dynamic world during covid-19 [9].

Based on the explanation above, the researcher took the title "Utilization of the E-Learning Platform as a Online Learning in the Time of the Covid-19 Pandemic" with the aim of wanting to find out which platform is easiest for students to use to support distance learning, so that it no longer interferes with the learning process, and makes it easier for students to absorb the material presented by the lecturer.

\section{METHOD}

This research is classified as a descriptive qualitative research by conducting a survey through data collection techniques from online questionnaires that have been filled in by students [10] UIN Maulana Malik Ibrahim Malang from the Faculty of Science and Technology and the Faculty of Tarbiyah and Teacher Training. The sample of students of class 2019 from the Chemistry Department and the entire batch of PGMI, PAI, PIPS, Mathematics Education Departments. The stages carried out in this research: 1) Formulation of a questionnaire instrument via google form which will be used for online data collection. The information contained in the questionnaire included: the use of e-learning platforms which were of great interest to students, 2) The online questionnaire compiled through the google form is tested for validity using expert opinion conducted by two instrument experts who also understand e-learning. 3) Collecting data with a validated questionnaire, as many as 315 students as respondents. 4) Research data obtained from the results distributed online to students which can then be analyzed descriptively to obtain research results. 


\section{RESULT AND DISCUSSION}

\subsection{Result}

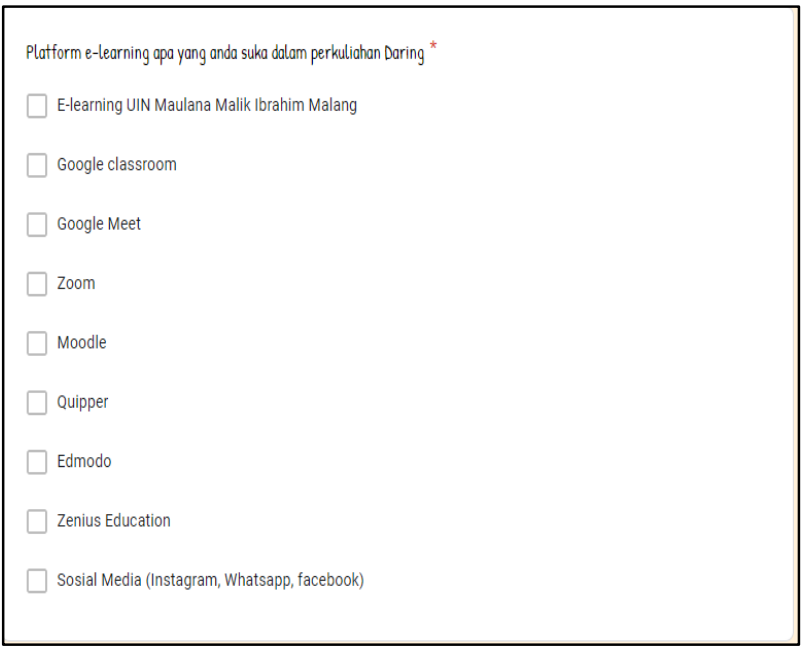

Figure 1: The e-learning platform Questionnaire

Student enthusiasm in filling out the questionnaire greatly affects the validity of the results of this study. Therefore, the filling out of this questionnaire was completely filled in accordance with what students experienced in learning during Covid-19. So that from the results of this study the lecturer was able to understand the desires of students about what platforms students were interested in during this pandemic. The research data was obtained through an online questionnaire in the form of a response to the utilization of e-learning platform as a support for online learning, then processed based on the observed aspects and descriptive exposure based on student responses.

The platforms mentioned in the questionnaire are as shown in Figure 1. Some of the platforms that have been written are familiar to all students. In distance learning activities, lecturers and students can use some of the platforms in figure 1 which are deemed appropriate in distance learning. There are only a few that are easy to implement or use by students, because it is possible that students have not fully used all of the platforms above so they do not understand.

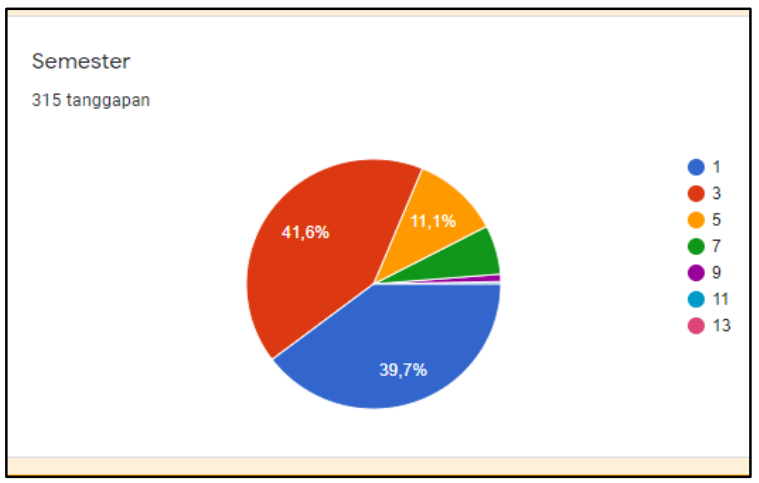

Figure 2: Data Respondent

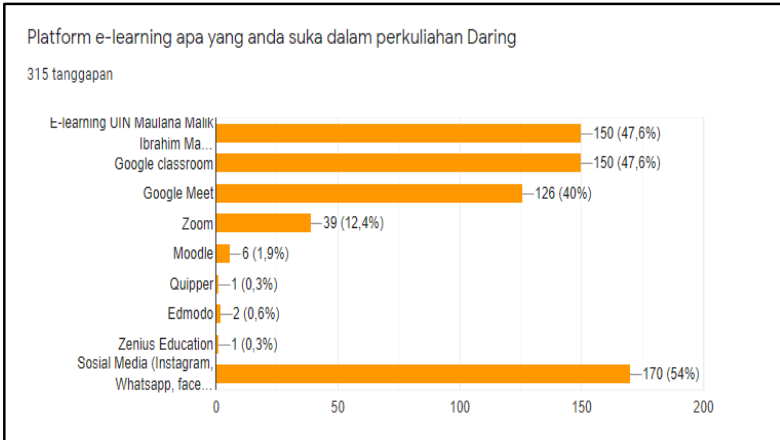

Figure 3: Percentage of e-learning platform utilization

Figure 2 shows that there were 315 respondents sampled in this study. Filling in the questionnaire was dominated by students in semester 1 (academic year 2020-2021) and semester third (academic year 20192020). As many as $41.6 \%$ of undergraduate students in semester 3 answered the most questionnaires and $39.7 \%$ in semester 1 .

The results of the online questionnaire show that $54 \%$ of respondents choose social media platforms (Instagram, Whatshapp, Facebook), this shows that almost more than half of the respondents use social media platforms. E-learning of UIN Maulana Malik Ibrahim Malang and google classroom are the platforms most used by lecturers and students for distance learning with a percentage of $47.6 \%$. As many as $40 \%$ of students and lecturers also use google meet for online learning. The use of the zoom platform is $12.4 \%$, this shows that more people use Google Meet than zoom because the zoom platform consumes more quota and is also limited by time. zoom can also be used for live online classes, web conferencing, webinars, video chats, and live broadcasts meeting [9]. Apart from the five platforms that have been mentioned, there are other platforms with a percentage below 2\% such as Moodle, Quipper, Edmodo, and Zenius education.

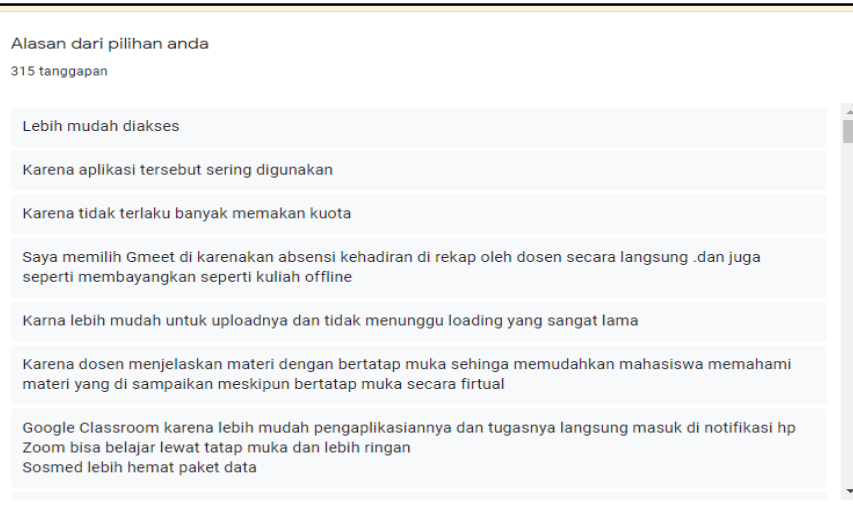

Figure 4: An example of the respondent's reason for choosing an e-learning platform 
About $70 \%$ of respondents gave a "more accessible" reason for using the e-learning platform they had chosen. Students choose a platform that is quota-efficient and easy to use, especially in learning.

\subsection{Discussion}

E-learning has a different features such as it is simply web-based training, which means You don't need to install software or CDs on your computer. Internet connection and a web browser are all you need. watch, listen and learn as training professionals demonstrate each lesson right on your computer screen[4]. The use of e-learning platforms during the Covid-19 pandemic has greatly helped distance learning activities. The existing platform includes innovative tools as a form of learning that emphasizes the student experience according to what Moedritscher said, there are three theories that underlie e-learning, one of which is constructivism theory. This theory states that experiences and interactions that play a role in the learning process must be considered in online learning, among others [11]: 1) Active learning, 2) Interactive, 3) Collaborative and cooperative, 4) Students must be controlled during the learning process, 5) Reflection, 6) Meaningful and illustrative, 7) Focus on interactive learning activities.

From the results of questionnaires sent by respondents, it shows that social media (Instagram, Whatshapp, Facebook) is able to activate interactive, collaborative and cooperative learning which is able to control students during learning and is able to provide reflection, so that there is a reciprocal between lecturers and students and able to realize closer learning.

The online questionnaire shows that social media (Instagram, Whatshapp, facebook) is the choice most chosen by respondents as many as $54 \%$, almost more than half of the respondents use social media platforms (Instagram, Whatsapp, Facebook). The WhatsApp platform is most often used because it makes it easier for teachers to control and control student learning activities during lecture hours and outside learning hours. Therefore, most of the students' expectations of using social media. In this case, the lecturer usually navigates students to use the WhatsApp group in learning. So, using the WhatsApp application is able to help and facilitate distance learning activities between lecturers and students who help in communication activities between lecturers and vice versa.

Whatsapp is used as a tool to convey information or material well, is user-centered, interactive and as a learning environment that has various conveniences for anyone, anywhere and anytime. By utilizing various attributes and sources of digital technology with the form of materials and other learning materials suitable for application in an open, flexible and distributed learning environment. Horton in his book E-Learning Tools and
Technologies (2003) [12].. Conditions like this no longer make platform problems difficult or confusing things that can cause passive students in distance learning (Argaheni, 2020), but already at the material stage and what tasks must be done in distance learning in order to provide experience. students [13].

The whatsapp platform is included in a platform that does not require a lot of quota (survey results) so that students are not burdened with quotas that must be used in learning to use WhatsApp besides WhatsApp has many supporting features in it. Whatsapp features that users can use are:

(a) Voice Notes: Record voice using voice notes to explain the material you want to explain, (2) Successfully sending, receiving, and reading messages: this mark can be used to identify active or passive students, (3) Send messages with various files: for example, you can send documents in the form of paper, ppt files, photos, videos, audio, locations, and contacts, (4) Avatar is a profile photo of whatsapp users to be able to view student profiles by displaying personal profile photos, (5) Email Conversation: can send all chats by email, (6) Forward: a feature used to forward or send back messages that have been received, (7) Smile Icons, a large selection of emoticons such as human expressions, buildings, weather, animals, musical instruments, cars, etc., are used to reward student assignments or responses, (8) Call: to make voice calls with other users, (9) Video Call: in addition to voice calls, users can also make video calls, (10) Block, to block other people's numbers, (11) Status, functions for notification to other contacts, namely users, (12) Make it bold, italic or strikethrough: Users can make sentences on WhatsApp with bold, italic, or strikethrough settings. To make a word or sentence bold, add an asterisk (*) to both sides of the phrase, for example * message *. To italicize a message, add an underscore like the following_message_. To cross out messages, add the following $\sim$ messages, 13) Put an asterisk: existing messages can be marked with a star and locked so that they are not deleted.

The use of social media platforms is indeed easy and in great demand by students, but it must be considered in its use. Good use of social media is to use polite language and communicate well. In this case students are required to understand communication rules and manners on how to communicate politely and be able to understand the right time when chatting on WhatsApp groups with lecturers so as not to interfere with lecturer activities outside of working hours.

Another platform with a high percentage of utilization is the e-learning of UIN Maulana Malik Ibrahim Malang. E-learning which is owned by the campus is the platform most used by students and lecturers in distance learning., E-Learning is an effective learning process that is generated by combining digital material delivery consisting of support and services in learning [14]. The 
percentage of this utilization is the same as google classroom with a percentage of $47.6 \%$. This platform is easy to use when used to it. For beginners, they will be confused because in e-learning there are several features for distance learning needs. This platform is also included in the group that does not need a lot of quotas. In this covid-19 condition, the economy is in decline, even though students have received additional quotas from the campus, but the choice of a platform with a low quota is very attractive to students so that it is sufficient in use for all learning.

E-learning tools are playing a crucial role during this pandemic, it aims to help instructors, schools, and universities facilitate student learning during periods of universities and schools closure. Besides, most of these systems are free which can help ensure continuous learning during this Coronavirus pandemic [2].

The features in the e-learning of UIN Maliki Malang are very complete, namely that they can provide assignments using the assignment application, chat with students or vice versa, students can also be given references according to their needs by utilizing file or folder applications that can be shared in e learning. There is also a quiz feature, a virtual face-to-face feature and many other features. So the e-learning of UIN Maliki Malang is really a complete package that can be used in distance learning.

In addition, there is a platform with a high percentage, namely Google classroom. The platform is also included in the platform used by students. The reasons written by students being drawn show that this platform can send notifications directly on cellphones or laptops every time the lecturer sends materials or assignments, making it easier for students to learn. Good learning must be integrated between face to face and virtual which is called a mixed learning model. Blended learning [15] is a learning experiment that combines various ways of delivery, models, and learning styles, introducing various choices of dialogue media between the facilitator and the person who is supported. Blended learning is also a combination of direct care (face-to-face) and setting up online, but more than that as an element of social interaction.

The survey shows that social media platforms are mostly used in conjunction with the UIN Maliki elearning platform or google classroom, while google meet is used when strengthening or strengthening material and can also be used as a face-to-face substitute, namely by virtual interaction using google meet. By switching from face-to-face learning to online learning, it requires a lot of effort and money. In this condition, of course, there are several obstacles faced by students, namely the availability of internet quotas, sometimes unstable networks, and other supporting devices such as laptops or cellphones that are less supportive. So that is why zoom or other applications only have a percentage below $2 \%$ in the use of distance learning [16].

This survey is expected to understand the current state of education. Bold learning can be done using a reliable platform not only for lecturers but also for students. A platform that is said to be of quality because bold learning is a platform that can attract student interest in learning so that lecturers are able to transfer knowledge according to educational goals. The platform used is really able to prepare students to receive material, and is able to motivate students to absorb knowledge well. So, using the platform is no longer a problem but a tool to make learning easier.

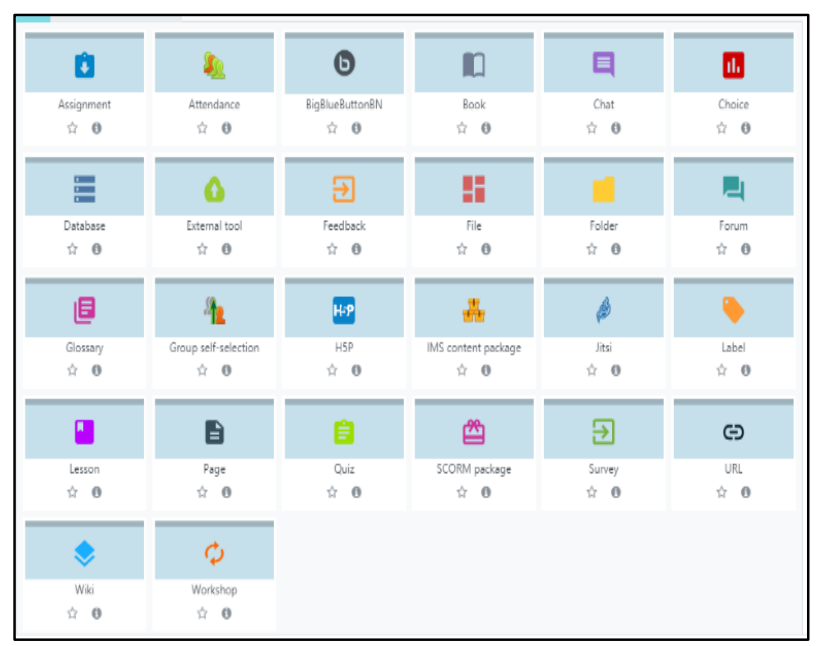

Figure 5: Features of the e-learning platform at UIN Maliki Malang

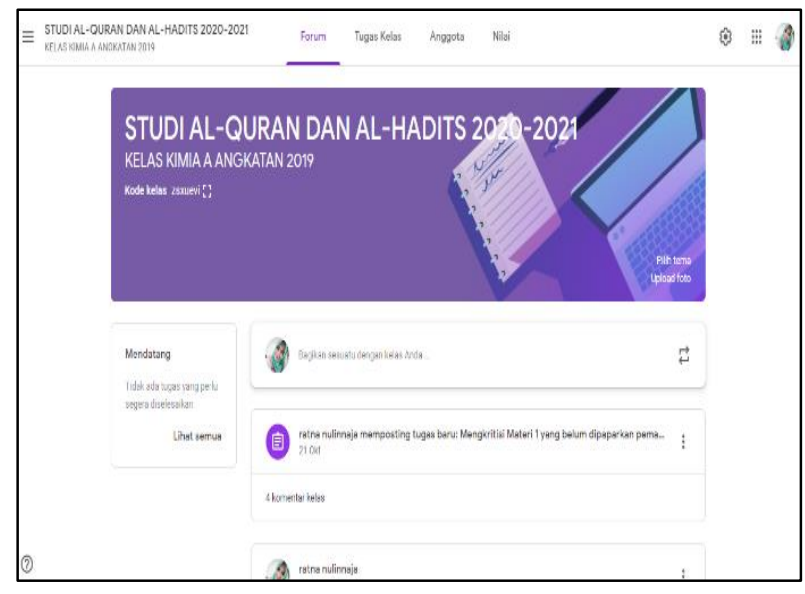

Figure 6: Display of google classroom platform features 


\section{CONCLUSION}

The condition of Covid-19 does not hinder the progress of education or learning at UIN Maulana Malik Ibrahim Malang, but still pay attention to the regulations that are enforced in accordance with the recommendations of the Minister of Education and Culture. Learning should continue even if it is done remotely using a platform that is freely available. Therefore, the researcher conducted a survey on the use of the platform in order to find out which platform students are most interested in. The results of selecting the platform with the largest percentage are expected to help facilitate learning so that learning runs according to the expected goals even with distance learning. The use of platforms is no longer an obstacle for lecturers to be able to provide motivation and delivery of material to students, and vice versa students no longer have difficulty understanding the material that has been delivered by the lecturer.

From a student survey of UIN Maulana Malik Ibrahim Malang, it was shown that the platforms most interested in by students with a percentage of 54\% were the e-learning platform of UIN Maulana Malik Ibrahim Malang and the google classroom platform. With the selection of the two platforms, it is hoped that they can help the learning process run smoothly online. In this case, the use of the google meet platform is also very necessary so that virtual interactions occur between lecturers and students.

This is in accordance with constructivism theory which states that learning must be an experience for students and Horton's opinion which states that elearning is web-based learning that can be accessed from the internet which is able to provide what is expected. procedures so as to be able to shape the quality of students in accordance with the expected goals. through face-to-face and virtual online learning processes or what is called blended learning, this is supported by Vaughan Waller.

\section{REFERENCES}

[1] W. Hadiwardoyo, "Kerugian Ekonomi Nasional Akibat Pandemi Covid-19," Baskara J. Bus. Enterpreneursh., vol. 2, no. 2, pp. 83-92, 2020, doi: 10.24853/baskara.2.2.83-92.

[2] S. Subedi, S. Nayaju, S. Subedi, S. K. Shah, and J. M. Shah, "Impact of E-learning during COVID-19 Pandemic among Nursing Students and Teachers of Nepal," Int. J. Sci. Healthc. Res., vol. 5, no. September, p. 68, 2020, [Online]. Available: www.ijshr.com.

[3] E. I. Azhar, D. S. C. Hui, Z. A. Memish, C. Drosten, A. Zumla, and Kemdikbud RI, "Edaran Tentang Pencegahan Wabah COVID-19 di Lingkungan Satuan Pendidikan Seluruh Indonesia," Infect Dis Clin North Am, vol. 33, pp.
$1-5,2020$

[4] B. Raad, "The Role Of E-Learning In Covid-19," no. April, 2020.

[5] N. Fatoni, Arifiati et al., "University Students Online Learning System During Covid-19 Pandemic: Advantages, Constraints and Solutions," Syst. Rev. Pharm., vol. 11, no. 7, pp. 570-576, 2020.

[6] M. F. Saifuddin, "E-Learning dalam Persepsi Mahasiswa," J. VARIDIKA, vol. 29, no. 2, pp. 102-109, 2018, doi: 10.23917/varidika.v29i2.5637.

[7] R. H. Permana, I. Ardiansah, D. Adiningsih, and M. Trisyani, "Tingkat Usabilitas Dan Kepuasan Evernote Sebagai Platform E-Learning Untuk Mata Kuliah Ilmu Dasar Keperawatan Di Fakultas Keperawatan Universitas Padjadjaran," J. Keperawatan Komprehensif, vol. 4, no. 2, p. 92, 2018, doi: 10.33755/jkk.v4i2.114.

[8] Afnibar and D. F. N, "Pemanfaatan Whatsapp Sebagai Media Komunikasi Kegiatan Belajar ( Studi terhadap Mahasiswa UIN Imam Bonjol Padang )," J. Komun. dan Penyiaran Islam, vol. 11, pp. 70-83, 2020.

[9] S. Dhawan, "Online Learning: A Panacea in the Time of COVID-19 Crisis," J. Educ. Technol. Syst., vol. 49, no. 1, pp. 5-22, 2020, doi: 10.1177/0047239520934018.

[10] A. H. Ali Sadikin, "Pembelajaran Daring di Tengah Wabah Covid-19," BIODIK J. Ilm. Pendidik. Biol., vol. 6, no. 2, pp. 187-192, 2020, doi: 10.17509/t.v6i2.20887.

[11] Edel.staff.unja,

"http://edel.staff.unja.ac.id/blog/artikel/TeoriBelajar-yang-Mendasari-E-Learning.html," 2016.

[12] Z. Zyainuri and E. Marpanaji, "Penerapan elearning moodle untuk pembelajran siswa yang melaksanakan prakerin," J. Pendidik. Vokasi, vol. 2, no. 3, pp. 410-426, 2013, doi: 10.21831/jpv.v2i3.1046.

[13] I. Mutia, "Kajian Penerapan E-Learning Dalam Proses," Fakt. Exacta, vol. 6, no. 4, pp. 278-289, 2013.

[14] R. T. Setiawardhani, "Pembelajaran Elektornik (E-learning) dan Internet dalam Rangka Mengoptimalkan Kreativitas Belajar Siswa," $J$. Ilm. Pendidik. Ekon. Unswagati, vol. 1, no. 2, pp. 82-96, 2013.

[15] Adminweb, "Pengertian dan Manfaat Model Pembelajaran Blended Learning," Sevima. 2018.

[16] E. S. Rosali, J. Pendidikan, and G. Universitas, "Aktifitas Pembelajaran Daring Pada Masa Pandemi Covid-19 Di Jurusan Pendidikan Geografi Universitas Siliwangi Tasikmalaya," Geogr. Sci. Educ. J. (GEOSEE, vol. 1, no. 1, pp. 21-30, 2020. 